\title{
QUALITATIVE AND QUANTITATIVE INDICATORS OF RAILWAY STATIONS
}

\begin{abstract}
The liberalization of the rail freight market has been booming in recent years. On a pan-European scale, new freight carriers are increasing year after year. Support for the liberalization of the railway sector is mainly implemented through the so-called railway packages and one of the tools is the quantitative and qualitative indicators of the individual railway stations. The relevance of the article is mainly to propose measures for railway stations, where freight transport is declining despite the liberalized market. These are main railway stations located on regional lines and railway stations with a smaller scope of transport work. The aim of this paper will be to propose measures to support freight transport in the Slovak Republic by setting minimum requirements (standards) for railway stations depending on their performance, respecting their current technical level of railway operation.
\end{abstract}

Keywords: railway station, freight carrier, railway transport

\author{
Juraj Čamaj ${ }^{1}$ \\ ${ }^{I}$ Faculty of Operation and Economics of Transport and Communications University of Žilina, \\ Univerzitná 8215/1,010 26 Žilina; +421/41 513 3434; juraj.camaj@fpedas.uniza.sk \\ Lenka Černá ${ }^{2}$ \\ ${ }^{2}$ Faculty of Operation and Economics of Transport and Communications University of Žilina, \\ Univerzitná 8215/1, 01026 Žilina; +421/41 513 3434; lenka.cerna@fpedas.uniza.sk \\ Adrián Šperka ${ }^{3}$ \\ ${ }^{3}$ Faculty of Operation and Economics of Transport and Communications University of Žilina, \\ Univerzitná 8215/1, 01026 Žilina; +421/41 513 3434; adrian.sperka@fpedas.uniza.sk \\ Ekaterina Zmeškal ${ }^{4}$ \\ ${ }^{4}$ Faculty of Operation and Economics of Transport and Communications University of Žilina, \\ Univerzitná 8215/1, 01026 Žilina; +421/41 513 3434; ekaterina.blinova@fpedas.uniza.sk
}

\section{Introduction}

Railway transport, whether passenger or freight one, should be a central part of a transport system of each developed country. The railway transport market has, however, been entered by the liberalisation through "railway packages". Among others it has led to a competition and entry of new carriers into the process of transportations. A carrier with all shares owned by the state and who - as part of the transformation process - has separated themselves from the infrastructure manager and railway undertaking operating passenger transport, still features the biggest performances even in spite of their decreasing trends. In 2018 there happened a slight decrease in transport performances in 515 thousand gross tonne-kilometres for this carrier (Železnice Slovenskej republiky, 2019). Even despite this drop the state carrier still has approximately $65 \%$ share on performances of freight railway transport in gross tonne-kilometres. For the comparison sake in 2012 it had up to $88.24 \%$ share on performances in gross tonne-kilometres (Gašparík, 2012).

In the view of the fact given above this article will deal with ZSSK CARGO carrier only. To determine quantitative indicators of railway stations we will study the number of wagonloads for 2018 and 2019, and to determine qualitative indicators we will study the usage of consignment notes in their electronic form. This news was introduced by the carrier on 1 January 2019 after several years of development. These indicators will be evaluated for Žilina operation centre. There in the article we will analyse national transportations only.

\section{Quantitative and qualitative indicators of railway stations}

A railway station is defined as a transport control centre with a track lead intended for controlling a sequence of trains, handling passengers and cargo (Přispěvatelé Wikipedie, 2005). Quantitative and qualitative indicators are divided by the kind of transport (passenger and freight transport). In each kind of transport there are some common and some distinct indicators studied. Table 1 presents some selected quantitative and qualitative indicators of railway stations for freight transport.

Table 1. Quantitative and qualitative indicators of railway stations in freight transport

\begin{tabular}{|l|l|}
\hline \multicolumn{1}{|c|}{ Quantitative indicators } & Qualitative indicators \\
\hline $\begin{array}{l}\text { number of submitted and issued } \\
\text { complete wagon load in } \\
\text { national and international } \\
\text { transport }\end{array}$ & $\begin{array}{l}\text { possibility to submit a } \\
\text { paper consignment note }\end{array}$ \\
\hline $\begin{array}{l}\text { number of freight trains in } 24 \\
\text { hours }\end{array}$ & $\begin{array}{l}\text { authority to issue } \\
\text { carriage documents }\end{array}$ \\
\hline number of stabling sidings & availability team track \\
\hline
\end{tabular}

Žilina operation centre comprises 660 transport points in total where operations related to cargo 
transportation can be performed (loading operations, commercial operations). They, however, also include stations which have certain limitations (a station not staffed with a carrier's worker, submission of national shipments only, a railway station without any technical equipment, etc.). Table 2 presents the structure of Žilina operation centre

Table 2. Structure of the Žilina operation centre (Železničná spoločnost' Cargo Slovakia, a. s., 2003)

\begin{tabular}{|c|c|c|c|}
\hline $\begin{array}{l}\text { Operation } \\
\text { centre }\end{array}$ & $\begin{array}{l}\text { Circuit of } \\
\text { operation }\end{array}$ & $\begin{array}{c}\text { Central } \\
\text { commercial } \\
\text { workplace }\end{array}$ & $\begin{array}{c}\text { Possibility } \\
\text { to submit a } \\
\text { paper } \\
\text { consignment } \\
\text { note }\end{array}$ \\
\hline \multirow{12}{*}{ Žilina } & Ružomberok & Lisková & $\begin{array}{l}\text { Bánovce nad } \\
\text { Bebravou }\end{array}$ \\
\hline & $\begin{array}{l}\text { Trenčianska } \\
\text { Teplá }\end{array}$ & $\begin{array}{l}\text { Trenčianska } \\
\text { Teplá }\end{array}$ & $\begin{array}{l}\text { Dolný } \\
\text { Hričov }\end{array}$ \\
\hline & \multirow[t]{10}{*}{ Zilina } & Žilina & Ladce \\
\hline & & & $\begin{array}{l}\text { Liptovský } \\
\text { Hrádok }\end{array}$ \\
\hline & & & Lisková \\
\hline & & & $\begin{array}{l}\text { Medzibrodie } \\
\text { nad Oravou }\end{array}$ \\
\hline & & & $\begin{array}{l}\text { Nové Mesto } \\
\text { nad Váhom }\end{array}$ \\
\hline & & & Púchov \\
\hline & & & Ružomberok \\
\hline & & & $\begin{array}{l}\text { Trenčianska } \\
\text { Teplá }\end{array}$ \\
\hline & & & Trstená \\
\hline & & & Žilina \\
\hline
\end{tabular}

The district of operation covers individual railway stations at which the railway undertaking provides its services. Figure 1 presents the number of railway stations falling under individual districts of operation.

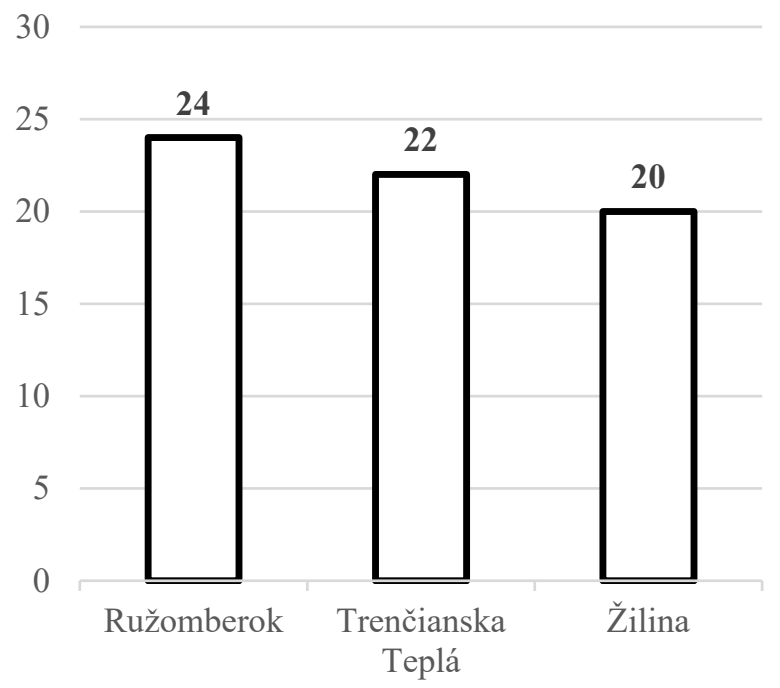

Fig. 1. Number of railway stations in individual operating district (Železničná spoločnost' Cargo Slovakia, a. s., 2003)
The chart makes it clear that the division of railway stations is comparatively even. There between the district of operation with the highest number of railway stations and the district of operation with the smallest number of railway stations exists the difference of four stations only.

\section{Comparison of the number of submitted national complete wagon load}

The basic quantitative indicator is represented with the number of received and submitted wagonloads by the shipper at the given railway station.

The carrier's transport regulations define a wagonload as follows:

a) goods transport of which requires at least one wagon,

b) goods comprising long indivisible objects on multiple wagons,

c) a rail vehicle on multiple wheels,

d) empty AVV wagons and other wagons submitted for transportation with at least one consignment note.

The haulage of individual wagonloads is realised by means of handling trains which feature a different periodicity. It depends on the actual load.

Direct consigner's trains or destination-routed block trains are categorised as freight express trains (NEx) or passing-through freight trains $(\mathrm{Pn})$. The category is assigned to a train on the basis of the assessment whether the load is collected per time (NEx trains) or per weight (Pn trains) (Gašparík \& Šulko, 2016).

Table 3 contains statistical data for the latest 2 years and it compares the number of submitted national wagonloads in Žilina operation centre.

Table 3. Quantitative and qualitative indicators of railway stations in freight transport (internal data of the railway undertaking)

\begin{tabular}{|l|l|l|}
\hline Railway station & $\begin{array}{r}\text { Year } \\
\mathbf{2 0 1 8}\end{array}$ & \multicolumn{1}{|c|}{$\begin{array}{c}\text { Year } \\
\mathbf{2 0 1 9}\end{array}$} \\
\hline Bytča & 0 & 14 \\
\hline Bytčica & 420 & 168 \\
\hline Diviaky & 0 & 30 \\
\hline Dolný Hričov & 0 & 140 \\
\hline Horná Štubňa & 0 & 8 \\
\hline Konská pri Rajci & 55 & 20 \\
\hline $\begin{array}{l}\text { Krásno nad } \\
\text { Kysucou }\end{array}$ & 279 & 59 \\
\hline Lietavská Lúčka & 188 & 110 \\
\hline Martin & 0 & 249 \\
\hline Príbovce-Rakovo & 0 & 29 \\
\hline Rajec & 103 & 29 \\
\hline $\begin{array}{l}\text { Sklené pri } \\
\text { Handlovej }\end{array}$ & 0 & 97 \\
\hline Turany & 0 & 3 \\
\hline Varín & 48 & 2 \\
\hline
\end{tabular}




\begin{tabular}{|l|l|l|}
\hline Vrútky & 0 & 112 \\
\hline Žilina & 314 & 105 \\
\hline Žilina-Teplička & 15 & 23 \\
\hline
\end{tabular}

Of the total number 66 railway stations recorded a wagonload submission in 2018, and 17 railway stations recorded a wagonload submission in 2019. I.e. in the last year there happened more than a twice increase in the wagonload submission. Despite a comparatively fast increasing trend of the submission there were and still are railway stations where a wagonload submission for the carrier did not occur either in 2018 or in 2019.

The loading at railway stations, where the submission did not occur, could have been negatively impacted with these selected factors:

a) formation of serried trains by another carrier,

b) a shift of shippers to another kind of transport,

c) a low flexibility of the carrier.

If this trend was repeated in the following years, the haulage and distribution of load should be modified. Handling trains which nowadays drive with a calendar restriction should drive as necessary and should be engaged every time there is a shippers' demand.

Table 4 presents a proposal for handling trains driving as necessary in regard to not performing the loading at individual railway stations.

Table 4. Proposal for the introduction of handling trains as needed within the Žilina operation centre (Železnice Slovenskej republiky, 2019)

\begin{tabular}{|c|c|c|}
\hline $\begin{array}{c}\text { Handling train } \\
\text { number }\end{array}$ & $\begin{array}{c}\text { Handling train } \\
\text { route }\end{array}$ & Note \\
\hline 85570 & $\begin{array}{l}\text { Král'ová Lehota - } \\
\text { Lisková }\end{array}$ & \multirow{5}{*}{$\begin{array}{l}\text { as needed } \\
\text { throughout the } \\
\text { route }\end{array}$} \\
\hline 85571 & $\begin{array}{l}\text { Lisková - Králova } \\
\text { Lehota }\end{array}$ & \\
\hline 85630 & $\begin{array}{l}\text { Púchov - } \\
\text { Trenčianska Teplá }\end{array}$ & \\
\hline 85631 & $\begin{array}{l}\text { Trenčianska Teplá } \\
\text { - Púchov }\end{array}$ & \\
\hline 85750 & $\begin{array}{l}\text { Trenčianska Teplá } \\
\text { - Nové Mesto nad } \\
\text { Váhom }\end{array}$ & \\
\hline 86500 & Žilina - Makov & $\begin{array}{l}\text { as needed in } \\
\text { the section } \\
\text { Čadca - Makov }\end{array}$ \\
\hline 86503 & Makov - Žilina & $\begin{array}{l}\text { as needed in } \\
\text { the section } \\
\text { Makov - Čadca }\end{array}$ \\
\hline 86550 & Trstená - Lisková & \multirow{7}{*}{$\begin{array}{l}\text { as needed } \\
\text { throughout the } \\
\text { route }\end{array}$} \\
\hline 86551 & Lisková - Trstená & \\
\hline 86560 & Tvrdošín - Lisková & \\
\hline 86561 & Lisková - Tvrdošín & \\
\hline 86620 & $\begin{array}{l}\text { Trenčianska Teplá } \\
\text { - Horné Srnie }\end{array}$ & \\
\hline 86621 & $\begin{array}{l}\text { Horné Srnie - } \\
\text { Trenčianska Teplá }\end{array}$ & \\
\hline 86630 & $\begin{array}{l}\text { Trenčianska Teplá } \\
\text { - Lednické Rovné }\end{array}$ & \\
\hline
\end{tabular}

\begin{tabular}{|l|l|}
\hline 86631 & $\begin{array}{l}\text { Lednické Rovné - } \\
\text { Trenčianska Teplá }\end{array}$ \\
\hline 86670 & $\begin{array}{l}\text { Trenčianska Teplá } \\
- \text { Rybany }\end{array}$ \\
\hline 86671 & $\begin{array}{l}\text { Rybany - } \\
\text { Trenčianska Teplá }\end{array}$ \\
\hline 87551 & $\begin{array}{l}\text { Nové Mesto nad } \\
\text { Váhom - } \\
\text { Trenčianska Teplá }\end{array}$ \\
\hline
\end{tabular}

In case of engaging trains as necessary the infrastructure manager does not provide a discount for the utilisation of a railway communication. It is also due to this reason why this measure is to be considered well and then based on the developing trend and economic profitability this measure is to be taken or not.

\section{Rate of use of paper and electronic consignment note}

With respect to digitalisation and automation of the company with emphasis put on making the transportations easier for customers, ZSSK CARGO carrier introduced the option to submit consignments using an electronic consignment note, as of 1 January 2019. With this step the shippers can create such a document from anywhere with the Internet signal coverage with no need to deliver in person. At the same time this step required an optimisation of jobs. The carrier merged workplaces of freight cash-desks into so called central commercial workplaces. Per Table 2 such workstations are dislocated in Žilina, Trenčianska Teplá and Ružomberok, as part of Žilina operation centre. The electronic communication with customers, in consideration of bigger volumes of transportations, is also performed in workplaces at other tariff points which, however, have remained separated from central commercial workplaces. The main task of central commercial workplaces lies in performing activities during the registration of transport performances in the area of the freight cash-desk, as well as the procedure to handle a consignment note before entering in the contract of carriage, during its period of validity and before its termination (Želeničná spoločnost' CARGO SLOVAKIA, a. s., 2020).

The electronic consignment note was in a testing operation already in 2018 (the testing operation started prior to 2018). The testing operation should have eliminated shortcomings so the system failures would happen to the least extent possible after running the operation for real.

The measure of introducing the electronic consignment note should, among others, contribute to the following (Želeničná spoločnost' CARGO SLOVAKIA, a. s., 2020):

a) a bigger interest in transportation by this carrier,

b) a higher comfort for the shipper,

c) better communication between the carrier and the shipper,

d) a higher satisfaction of the customer. 
Figure 2 shows a graphical comparison of submission of individual wagonloads at railway stations for Žilina operation centre using a printed and electronic consignment note in 2018 and 2019.

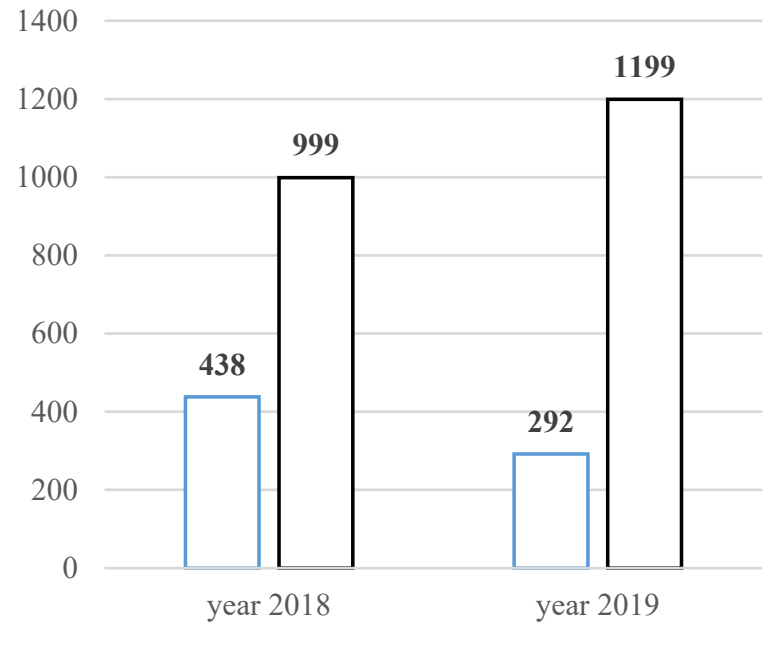

$\square$ Paper consignment note $\square$ Electronic consignment note

Fig. 2. Comparison paper and electronic consignment note (internal data of the railway undertaking)

The data makes it clear that even during the testing operation in 2018 the number of wagonload submissions in electronic form of the consignment note was higher than in its printed form. Altogether there were 1,437 wagonloads submitted for Žilina operation centre in 2018, out of which 999 were submitted per the electronic consignment note, which is almost $70 \%$.

In 2019 out of 1,491 wagonloads submitted for Žilina operation centre in 2018 there were 1,199 wagonloads submitted per the electronic consignment note, which is almost $81 \%$. A year-on-year increase then fluctuates at the level of almost $11 \%$ and it conveys the information that submitting the wagonloads per the electronic consignment note is more and more popular among the customers. Thus there is a probability that the majority of tariff points where it is still possible to submit a consignment note in its printed form will have to shift to an electronic submission of wagonloads.

\section{Conclusion}

A progressive liberalisation of railway freight transport has brought many changes, whether for shippers, the infrastructure manager or carriers. Each of these entities concerned tries to react to these changes differently. The carrier must look after the biggest satisfaction of a shipper in the competitive fight for the shipper. One of the options is to improve the quality and to make the provided services faster in higher and higher quality. And the electronic consignment note can serve for the purpose of achieving such a defined objective. At the conclusion we must highlight that each railway undertaking should optimise transport-carriage processes and improve their quality so the customers will return back and utilise their services again.

\section{Acknowledgement}

The paper was supported by the project EUREKA E!3156 - ERIC Mobile - "European Rail Information Centre in Freight Transport for End-users on Mobile Platforms" at Faculty of Operations and Economics of Transport and Communication, University of Žilina, Slovakia.

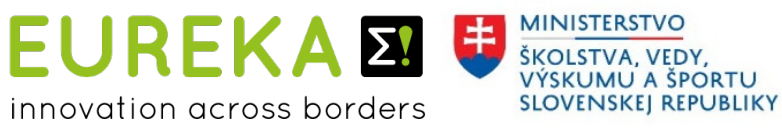

\section{References}

Gašparík, J., 2012. Úvod do problematiky. [Online] Available at: $\underline{\text { https://fpedas.uniza.sk/ gasparik/1pojmy.pdf }}$ [Cit. 27 Január 2020].

Gašparík, J. \& Šulko, P., 2016. Technológia železničnej dopravy: Líniové dopravné procesy. Žilina: EDIS ŽU.

Želeničná spoločnost' CARGO SLOVAKIA, a. s., 2020. Centrálne komerčné pracoviská a elektronický nákladný list. BUSINESS ZSSK CARGO, I(2), p. 12.

Železnice Slovenskej republiky, 2019. O nás: Výročné správy. [Online] Available at: https://www.zsr.sk/files/o-nas/vyrocnespravy/vyrocnasprava2018.pdf [Cit. 27. Január 2020].

Železničná spoločnost' Cargo Slovakia, a. s., 2003. Zoznam stanic v Slovenskej republike čast’ Nákladná preprava. Košice: Železničná spoločnost' Cargo Slovakia, a. s.. 